\section{Web Resources}

\section{Sources of Aid}

\section{Scholarship Search}

www.fastweb.com

College Savings Plan Network www.collegesavings.org

\section{AmeriCorps}

www.americorps.gov

City Year

www.cityyear.org

\section{JobCorps}

www.jobcorps.gov

State Resources

www. finaid.org/state

State Residence Requirements www.finaid.org/stateresidency

\section{Student Tax Info}

www.irs.gov/individuals/students

\section{Financial Aid Applications}

\section{CSS/Financial Aid PROFILE} profileonline.collegeboard.com

\section{FAFSA}

www.fafsa.ed.gov

\section{FAFSA PIN Registration}

www.pin.ed.gov

\section{FAFSA 4Caster}

www.fafsa4caster.ed.gov

FAA (Access to Central Processing System) www.fafsa.ed.gov/FOTWWebApp/faa/faa.jsp

Bureau of Citizenship and Immigration

www.uscis.gov

Selective Service System

www.sss.gov

Social Security Administration

www.ssa.gov

\section{Financial Aid Information}

Fastweb

www.fastweb.com

\section{FinAid}

www.finaid.org

\section{Fastweb College Gold}

www.collegegold.com

Federal Student Aid for Students studentaid.ed.gov

Financial Aid Calculators www.finaid.org/calculators

FTC Project Scholarship Scam www.ftc.gov/scholarshipscams

\section{Mapping Your Future}

www.mappingyourfuture.org

Student Gateway to the US Government www.students.gov

The Guide to Federal Student Aid studentaid.ed.gov/guide

\title{
2012-2013 Calendar
}

September 2012

4 - LSAT Registration Deadline for $10 / 6$ Test 8 - ACT Test Day (Selected States)

14 - GRE Registration Deadline for 10/20 Test 14 - LSAT Late Registration Deadline for 10/6 Test 16-19 - NCAN National Conference

21 - GRE Late Registration for 10/20 Test

\section{October 2012}

\section{6 - SAT/LSAT Test Day}

12 - GRE Registration Deadline for 11/17 Test

16-19 - NSPA National Conference

19 - GRE Late Registration for 11/17 Test

20 - GRE Test Day

24-26 - College Board National Forum

27 - ACT Test Day

29 - LSAT Registration Deadline for 12/1 Test

\section{November 2012}

\section{3 - SAT Test Day}

7-11 - National Distance Learning Week

9 - LSAT Late Registration Deadline for $12 / 1$ Test 17 - GRE Test Day

\section{December 2012}

\section{1 - LSAT Test Day}

3 - SAT Test Day

8 - ACT Test Day

\section{January 2013}

Complete FAFSA and submit ASAP to maximize chances for aid

4 - GRE Registration for 2/9 Test

8 - LSAT Registration for 2/9 Test

11 - GRE Late Registration for 2/9 Test

18 - LSAT Late Registration for 2/9 Test 26 - SAT Test Day

\section{February 2013}

Financial Aid Awareness Month

Submit 2012-2013 FAFSA

9 - ACT / LSAT / GRE Test Day (except in NY)

\section{March 2013}

9 - SAT Test Day

20-24 - ACA Conference

\section{April 2013}

National Financial Literacy Month

13 - ACT Test Day

15 - Federal income tax due for 2012

May 2013

1 - National Candidates' Reply Date

4 - SAT Test Day

\section{June 2013}

1 - SAT Test Day

8 - ACT Test Day

30 - Last day to submit 2012-2013 FAFSA

\section{Summer 2013}

Refer to the GMAT, LSAT and MCAT for more test date information

\section{Scholarship Scams}

\section{Scam Warning Signs}

- You have to pay a fee

- Money-back offers or guarantees

- Credit card or bank account

information required

- Provides "exclusive" information

Scams: "Phishing"

\& "Pharming"

"Phishing"

- Unsolicited emails that bear the logo of your bank or credit card

- Appear legitimate but are traps to lure you into giving out your personal or account information

NEVER give out Social Security, credit card or bank account numbers to unsolicited emails or calls

"Pharming"

- Unsolicited emails that encourage you to visit a website or click on suspicious links

- Make sure your inbox spam filters are up to date

BE CAREFUL about giving out your contact information or email address

\section{Reporting Scams}

National Fraud Information Center (NFIC) File an online complaint at www.fraud.org

Federal Trade Commission (FTC) File an online complaint at www.ftc.gov/scholarshipscams, call 877-FTC-HELP (877-382-4357) or write to:

Federal Trade Commission Consumer Response Center 600 Pennsylvania Ave., NW Washington, DC 20580

State Attorney General's Office File your complaint with the Consumer Protection Division in your state. Visit www.naag.org to find your state Attorney General's Office

US Postal Inspection Service (USPIS) File an online complaint involving mail fraud at postalinspectors.uspis.gov, call the Crime Hotline at 877-876-2455 or write to:

Inspection Service Support Group 222 S. Riverside Plaza, Ste. 1250 Chicago, IL 60606-6100

Better Business Bureau (BBB) File an online complaint about a business at www.bbb.org or call 703-276-0100 